\title{
An exploration of personal, relational and collective well-being in nursing students during their training at a tertiary education institution
}

\author{
Authors: \\ Kirsten D. Watkins ${ }^{1}$ \\ Vera Roos ${ }^{1}$ \\ Engela Van der Walt ${ }^{2}$

\begin{abstract}
Affiliations:
${ }^{1}$ School for Psychosocial Behavioural Sciences, North-

West University, South Africa

${ }^{2}$ School of Nursing Sciences, North-West University,
\end{abstract} \\ South Africa \\ Correspondence to: \\ Vera Roos \\ Email: \\ vera.roos@nwu.ac.za \\ Postal address: \\ Private Bag X6001 \\ North-West University, \\ Potchefstroom 2520 \\ South Africa \\ Dates: \\ Received: 16 Mar. 2010 \\ Accepted: 18 Feb. 2011 \\ Publisher: 02 Sept. 2011 \\ How to cite this article: \\ Watkins, K.D., Roos, V. \& \\ Van der Walt, E., 2011, 'An \\ exploration of personal, \\ relational and collective \\ well-being in nursing \\ students during their training \\ at a tertiary education \\ institution', Health SA \\ Gesondheid 16(1), Art. \#552, \\ 10 pages. doi:10.4102/hsag. \\ v16i1.552
}

C) 2011. The Authors. Licensee: AOSIS OpenJournals. This work is licensed under the Creative Commons Attribution License.
The well-being of nursing students has become crucial because of the multidimensional challenges that nursing professionals have to deal with. A community psychology framework was adopted in this study. The aim of the research was to explore the different dimensions of well-being as described by nursing students. A purposive and availability sample was used to gather qualitative data (interviews, focus groups and visual presentations) during 2008 and 2010 from first-year nursing students, which were thematically analysed. The emergent themes were grouped according to personal, relational and collective well-being. The findings indicated that nursing students' personal well-being was undermined by a lack of autonomy, feelings of uncertainty, and feelings of pressure and disillusionment with the nursing profession and their training. Personal well-being was also described in terms of dispositional optimism and the need for a sense of purpose and deeper meaning. Relational well-being was expressed by the nursing students in relation to their friends, family and lecturers. The different relationships were important sources of comfort and encouragement. Their collective well-being was threatened by a challenging work environment, lack of role models in clinical settings as well as incongruence between theoretical training and practical application. Recommendations for improving the different dimensions of well-being are suggested.

Die welsyn van verpleegkundestudente het deurslaggewend geword as gevolg van die uiteenlopende uitdagings wat verpleegkundiges moet hanteer. 'n Gemeenskapsielkunde raamwerk is in hierdie studie gebruik. Die doel van die navorsing was om die verskillende dimensies van welsyn van verpleegkundestudente te ondersoek. 'n Doelgerigte en beskikbaarheidsteekproef is gebruik om kwalitatiewe data (onderhoude, fokusgroepe en visuele voorstellings) wat gedurende 2008 en 2010 van eerstejaar-verpleegkundestudente bekom is, deur middel van tematiese inhoudsontleding te analiseer. Die temas wat na vore gekom het, is gegroepeer volgens persoonlike, verhoudings- en gemeenskaplike welsyn. Die bevindinge het aangedui dat die verpleegkundestudente se persoonlike welsyn ondermyn word deur ' $n$ gebrek aan outonomie, gevoelens van onsekerheid en om onder druk te verkeer, asook 'n ontnugtering met die verpleegkunde professie en opleiding. Persoonlike welyn is ook beskryf in terme van ' $n$ optimistiese ingesteldheid en die behoefte aan sinvolheid en ' $n$ dieper betekenis. Verhoudingswelsyn is deur die verpleegkundestudente uitgedruk in terme van hulle verhouding met hul vriende, familie en dosente. Die verskillende verhoudings word as belangrike bronne van ondersteuning en aanmoediging geag. Gemeenskaplike welsyn word bedreig deur ' $n$ uitdagende werksomgewing, die afwesigheid van rolmodelle in die kliniese omgewings asook die teenstrydigheid van die teoretiese opleiding met die praktiese toepassing daarvan. Aanbevelings vir die bevordering van welsyn in die verskillende dimensies word voorgestel.

\section{Introduction}

Nursing students are part of the larger nursing community, and the well-being of these students is closely related to that of the community in which they function. Various reports indicate that the South African nursing profession is in crisis. The Hospital Association of South Africa predicts that by 2011, South Africa will experience a shortage of approximately 19000 nurses (McGrath 2003:10). The Organisation of Economic Co-Operation and Development estimated that in 2005 as many as 35000 South African nurses were working outside South Africa and/or outside the health care system (Oosthuizen \& Ehlers 2007:15). According to the South African Nursing Council, statistics released toward the end of 2007 revealed that 42000 of the 107000 nurses at that time were over the age of 50 and only $3 \%$ of the nurses were younger than 30 years (Brannigan 2009:33). Brannigan (2009:36) maintains that South Africa continues to experience a shortage of nurses largely because medical professionals are lured away from the country. Furthermore, 
registered nurses in South Africa often suffer from burnout, unsatisfactory working conditions, low salaries and limited career advancement opportunities (Brysiewicz \& Bruce 2008:128; Jacobs \& Roodt 2008:64; Minnaar \& Selebi 2009:29).

The consequence of the 'brain drain' is an excessive workload, not only within the nursing profession but in many other professional occupations as well, for those remaining in the profession and in the country (McDonald \& Crush 2000:5). The resultant work pressure, especially for nurses working in the public sector, increases the risk of burnout, a syndrome marked by emotional exhaustion and over-extension as well as a depersonalised attitude toward patients (Alacacioglu et al. 2009:543; Brysiewicz \& Bruce 2008:129).

\section{Problem statement}

In a recent study, the nurses in the sample group reported that they enjoyed what they were doing and wanted to look after their patients, but they added that the circumstances in which they worked were far from satisfactory and that they lacked the basic necessities to carry out their jobs properly (Minnaar \& Selebi 2009:32). More specifically, the nurses reported that patients were dying because they did not have the appropriate equipment available in the hospitals to administer the necessary care (Oosthuizen \& Ehlers 2007:15). The nurses also reported inconsistencies in hospital procedures and stated that supervisors did not give them the opportunity to make their own decisions and thus they did not develop a sense of autonomy (Minnaar \& Selebi 2009:32). In Minnaar's and Selebi's study, as many as $35.7 \%$ of the respondents reported that they did not receive adequate support from their more experienced nursing colleagues and that they were not encouraged by their supervisors to render services of high quality. The situation prevailing in the nursing community at present is reflected in the training of the nurses. For example, factors such as supervision, exhaustion, procedural inconsistencies and stress are experienced in the training of nurses as well as in the nursing profession itself.

From the aforementioned, it is clear that a pressing need exists for nursing students to graduate and enter the workforce to alleviate the serious staff shortage. It is against this background, coupled with the large number of first-year students who drop out of training programmes, that it was decided to explore the experiences of nursing students during their first year of study. The research question that guided this research is: 'What are the dimensions of well-being as expressed by nursing students?' This is an important question because professional nurses are expected to promote the well-being of the people entrusted to them. For the purpose of this study, well-being refers to personal well-being, wellbeing in relation to people who form part of the community, and perceived well-being in relation to the broader context, which in this instance is the nursing profession (Nelson \& Prilleltensky 2005:54). The adoption of this framework to understand nursing students within the broader context in which they function, gives the study an ecological perspective and subjects it to the assumptions underlying community psychology (Nelson \& Prilleltensky 2005:5). A community psychology framework aids researchers to understand human behaviour in different contexts with the focus on the dynamic nature of people, relationships and situations.

\section{Aims of the study}

The aim of the research is to explore the different dimensions of well-being as described by nursing students.

\section{Contribution to field}

The purpose of the research is to promote the well-being of nursing students during their training. They are expected to promote the well-being of people and to enter the workforce to alleviate the serious staff shortage.

\section{Research method and design Design}

A qualitative, exploratory and contextual research design was used to explore the different dimensions of well-being as described by nursing students.

\section{Research context and materials}

The research context was the North-West University on the Potchefstroom Campus. The group of nursing students was defined as a relational community for the purposes of the study. According to Dalton, Elias and Wandersman (2003:172), a relational community is a group of individuals who share a more abstract common interest or belief. Purposive and availability sampling was used to obtain the participants for data collection during 2008 and 2010. Of the 32 first-year nursing students in 2008, 28 students chose to participate in the study. The final group of participants that participated towards the end of their first year in 2008 comprised 22 female students and 1 male student of which 18 participants were Afrikaans-speaking and 5 were Englishspeaking. The same group of first-year nursing students as in 2008 participated in the second phase of data collection at the beginning of their third year. As a consequence to students dropping out of the nursing study programme, only 18 of the 32 original students commenced their third year of training in 2010. These remaining 18 students included 2 students who had declined to participate in the original study which brought the study population to 16 students. Of these 16 students, 4 White female students agreed to participate in the second phase of data gathering in 2010.

\section{Data collection methods}

Qualitative data gathered during the study in 2008 included collages and the Mmogo-method ${ }^{\mathrm{TM}}$ (Roos 2008, in press), as well as focus group discussions, personal diaries and indepth interviews.

Visual data were obtained when participants were requested to construct collages that represented their dreams for their nursing profession. The objective was to explore the 
students' motivation for studying nursing and possibly to identify factors that may contribute to the drop-out rates of nursing students. The participants grouped themselves for the purpose of the focus group discussion in the following manner:

- the 5 English speaking participants grouped themselves together (Group 1)

- the 23 Afrikaans speaking participants divided into 3 groups: 1 group with 4 participants (Group 2)

- another with 9 participants (Group 3)

- and the last group (Group 4) comprised 10 participants.

Discussions during the focus group were centred on collages and the meanings that the students attached to the pictures they included in the collages.

The Mmogo-method ${ }^{\mathrm{TM}}$ involves the construction of the participants' lived experiences, by using malleable clay, dried grass stalks and colourful beads. These materials are used as a projective method because participants were asked to use the materials and to build anything about their experiences of being a nursing student. The visual data were regarded as participants' reflections on the social structures of which they are part of (Roos in press).

During the in-depth interviews, four participants' experiences of being nursed and nursing others were acquired. Interviews were recorded with the use of a digital voice recorder and were then transcribed verbatim. The interviews were used to gain a better understanding and to learn from the participants what they viewed as important factors during their training and how they understood their own experience.

Additionally, one focus group discussion was held during 2010. Four students participated in this focus group and the discussions allowed the participants to interact and to contribute valuable data and insights regarding their experiences of well-being, as well as in reflecting on their experiences during 2008. A focus group discussion is a socially oriented research method that facilitates the acquisition of data in a social environment (Babbie 2007:308). The participants were given an open-ended instruction: 'Please tell us how you are experiencing your training as a nursing student at present and reflect on your first year of training.'

\section{Data analysis}

The qualitative data gathered during 2008 and 2010 were analysed thematically to find common themes and to identify salient issues (Green \& Thorogood 2004:177). The following phases of thematic analysis suggested by Braun and Clarke (2006:87-93) guided the data analysis:

- Acquiring familiarity with the data. During this phase, the researchers repeatedly listened to audio recordings of the interviews so that they could familiarise themselves with the content and begin to formulate possible themes.

- Generating initial codes. Coding involved taking chunks of text and placing them in specific categories in such a way as to enable later analysis of the data (Babbie 2007:384). Data were organised into meaningful clusters that became salient during Phase 1, and the clusters were colour-coded on the transcribed data sets.

- Searching for themes. Codes were grouped into themes that were arranged in a mind map so that particular attention was paid to codes that linked up with the research question.

- Reviewing themes. Some themes from Phase 3 were grouped together, and some less important themes fell away. Data were reread to ascertain whether the themes represented the data adequately.

- Defining and naming themes. Each theme was defined and explained (Braun \& Clarke 2006:82).

- Producing the report. The report identified the emergent themes and related the analysis to the research question and the literature review. The data that were gathered during 2008 and 2010 were merged and reported jointly as themes in terms of the different relational dimensions of well-being.

\section{Results}

Themes that emerged from the data gathered during the first and the second phase of the study relate to the three dimensions of well-being as described by Prilleltensky and Prilleltensky (2006:12), namely personal, relational and collective well-being. Well-being in this study refers to the complexity inherent in the multifaceted profession of nursing and is understood as the optimal functioning of the person in relation to other people as well as in the broader context of the nursing community.

The themes and subthemes were visually presented (Table 1).

\section{Theme 1: Personal well-being}

In this study, personal well-being means that individuals have the autonomy to make decisions in their lives, feel a sense of control over the pressures and experience optimism and meaning in their lives. The following subthemes emerged during the thematic analysis.

\section{Lack of autonomy}

The data indicated that the participants did not experience autonomy in their first year of training. Autonomy is defined here as the independent judgement by people to effect a

TABLE 1: Visual presentation of the themes and subthemes of nursing students experiences of their training.

\begin{tabular}{|c|c|}
\hline Themes & Experiences \\
\hline $\begin{array}{l}\text { Theme } 1 \\
\text { Personal well-being }\end{array}$ & $\begin{array}{l}\text { - Lack of autonomy } \\
\text { - Feelings of uncertainty } \\
\text { - Feeling under pressure } \\
\text { - Disillusionment with the nursing profession and the training } \\
\text { - Dispositional optimism } \\
\text { - Sense of purpose and deeper meaning }\end{array}$ \\
\hline $\begin{array}{l}\text { Theme } 2 \\
\text { Relational well-being }\end{array}$ & $\begin{array}{l}\text { - Friendship } \\
\text { - Family } \\
\text { - Lecturers }\end{array}$ \\
\hline $\begin{array}{l}\text { Theme } 3 \\
\text { Collective well-being }\end{array}$ & $\begin{array}{l}\text { - Challenging working environment } \\
\text { - Lack of role models in clinical practice } \\
\text { - Incongruence between theoretical and practical training }\end{array}$ \\
\hline
\end{tabular}

Source: Authors' original data 
desirable outcome (Keenan 1999:561). The participants had no autonomy or say over their practical-training hours. They believed that they should have been given the freedom to allocate their own training times so that they could decide when they could go home on weekends and when they could not. They also believed that they were not allowed to use their own initiative when faced with difficult situations in their practical training. They felt as though all they were allowed to do was to stand back, to observe and to let things happen to them and around them.

The following extracts illustrate their experience of a lack of autonomy:

'Our lecturers want to organise everything for us. They want to plan from what time to what time we have to work, when we must study, when we must do our assignments. It's as though they want to organise every aspect of our lives and that irritates me immensely.

'You do just what you have to do, because someone else above you makes decisions for you.'

'The old man gasps, but you just have to stand and watch until he dies, because there's nothing we can do for him.'

(Study participants)

The focus group with the third-year participants confirmed the lack of autonomy they had expressed during their first year although it appears that they were granted more autonomy in their third year. The participants still experienced a lack of autonomy in government hospitals but reported that they had more responsibility in private hospitals, which made them feel more empowered:

'By your third year you are given greater responsibility, now you have do something and that makes it more enjoyable.'

'In the government you can't take the initiative and do something yourself, because they will find fault with it.'

(Study participants)

\section{Feelings of uncertainty}

The participants reported feelings of uncertainty about how to handle some of the situations they were confronted with during their training. This was especially evident in their practical training where they described numerous unfamiliar situations that they did not know how to handle. They often felt that they were thrown in at the deep end and that they were expected to cope with situations that, realistically, they could manage only with time and more experience. They lacked a sense of competence in dealing effectively with the variety of stressful situations they were exposed to, which left them feeling overwhelmed and uncared for:

'We didn't know what to do. It was terrible.'

'We just had no idea what to do and the nurse was carrying on so much that we literally and figuratively just ignored her.'

'At the beginning we felt as though we had been thrown in at the deep end, and we can't swim.'

(Study participants)

\section{Feeling under pressure}

Many of the participants reported that the emotional, time and academic pressures they had to contend with made them feel stressed and often unable to cope. These feelings were exacerbated by their practical-working hours and participation in first-year activities:

'You are actually so tense because there are so many people around you and they expect that you already know how to do it when you get there.'

(Study participant)

It also seemed, however, that the participants devised ways of dealing with their stress. They realised, for example, that they had to plan and prioritise, which made it easier for them to handle the various pressures they were subjected to:

'Some people do not allocate their time correctly enough and this becomes a problem, and they just feel like giving up, because I can't take the pressure.'

'Through that journey it was so hectic and all that, but it helped me manage my time, it helped me to work under a lot of pressure.'

'Now it is a part of our lives, we are used to the work load, you don't get the time to really be yourself... you have a headache and a stomach ache ... but no one asks you how you are feeling.'

(Study participants)

The participants also reported that their third year was emotionally stressful for them:

'The emotional stress was too much for us at that stage because we didn't really know how to work with the cadavers or with people or patients dying.'

'We didn't know how to handle it.'

(Study participants)

\section{Disillusionment with the nursing profession and training}

The participants reported not knowing, and not prepared for what the nursing profession and the training entailed prior to their commencing the BCur degree course. The interviews with the participants revealed that their expectations did not correspond with the reality. Some of the participants said that they had consulted the internet about the course but could not find any clear outline of the course and the hours they would have to spend on practical work on top of the academic work load. Some of the participants were not aware that practical training was part of the first-year curriculum, and others expressed their disappointment when they discovered that they would neither be able to go home every second weekend nor for a portion of the university recess because of the compulsory practical-hours. The participants expected the profession to be one of caring and nurturing, but they found that the reality was a harsh environment where they had to abandon tenderness in order to manage the tough challenges that confronted them. They expressed themselves as follow:

'I personally feel that no one prepared us and told us what the course really is about.'

'The idea that a person has when you get to the hospital and you see the nurses, is very different from the way you experience it when you get there and work.'

(Study participants)

The participants also expressed their disappointment with the state of the hospitals, as well as the manner in which patients were treated in hospital: 
'None of us expected that shock of the dirty, gross place.'

'The other day I wiped an alcohol swab on a patient's arm it was brown.'

(Study participants)

When the participants reflected on their experiences, they compared their current level and status of training and expressed some relief in realising that some of their expectations about nursing had been confirmed. They realised then that they could indeed make a difference to patients' lives, which was not their experience in their first year:

'The picture you have in your mind (of nursing) you only get to see now.'

'I had the satisfaction of the things I could do.'

(Study participants)

\section{Dispositional optimism}

Dispositional optimism refers to an attitude where positive outcomes are generally expected, a mind-set that has been linked to a range of positive psychological and emotional benefits (Gillham 2000:165). It seems as though the participants focused on the positive aspects of nursing rather than on the negative, which might have been difficult in their first year of training:

'Yes, I also remember the negative, but I just focus on the positive.'

'It doesn't only concern the negative things because in every negative thing, there's a positive thing that can be taken from it.

'I think you make it pleasant for yourself.'

'During your first year, you only see the unpleasant. That's why everyone quits.'

(Study participants)

\section{Sense of purpose and deeper meaning}

To have a purpose in life and to see a deeper meaning in life means to pursue worthwhile goals and to achieve a sense of fulfilment (Recker \& Wong 1988:221). Mascaro, Rosen and Morey (2004:845) refer to meaning in life as the intentions that underlie behaviour, that is, the reasons for doing something. The participants described their experiences during their training with a sense of knowing they had an important contribution to make as nurses. They conveyed the realisation that they had a specific role to fulfil regardless of their own personal challenges:

'God is the light in our lives because He leads us to do His will in the hospital.'

'I want at the end of it, when I'm 75 or 80 to stand in front of God and say: "With all that You have given me, I have not kept for myself. I have given all that I could to the people to the best of my ability, in the service of men."'

'The knowledge of higher meaning for yourself that there is somebody, a bigger presence.

'Nursing is not just a job, it's a love you have, for the work, the people and to help people.'

'I see it as another challenge to prove to them that I am here for a reason.'

'We are going to be touching lives on a minute by minute basis. In that we will be building lives.'

'I want to make a difference.'

(Study participants)

\section{Theme 2: Relational well-being}

Relational well-being refers to the care and support the participants experienced in their relationships.

\section{Friendship}

Friendship forms where two or more people are involved in a relationship that requires loyalty and trust, that involves close and frequent interaction and that is regarded as social support (Bukowski, Newcomb \& Hartup 1996:2). Social support is the protective role that a friendship relationship can play in mitigating the effects of stress and in contributing to the psychological and physical health of an individual (Marsh 1992:62). Close personal relationships play a significant role in the lives of most people. The nursing students formed close personal relationships with one another and supported each other during their studies:

'My one friend with whom I am studying, we help each another a lot.'

'Everyone in our group is friends.'

'Through death and pain and heartache we remain the support for one another.

'Your family may perhaps be far away, so your friends are your only support.'

'It's those bonds that we have created when we work together that are going to make us forever friends.'

'We support each other, we motivate each other.'

'You search for that special friend that accepts you the way you are.'

'You have at least one friend that pulls you through en shares in your heartache and anger and frustration.'

'An important thing that we are missing is that you have at least one friend that pulls you through.'

(Study participants)

\section{Family}

The participants reported that their family, and in particular their parents, supported and encouraged them. Many of the participants had to move away from their families and were unable to visit them regularly. They missed spending time with their families and placed a high value on staying in touch with their parents, particularly with their mothers:

'So if I have a problem I can immediately go to my mom and ask her what to do. Then she will first tell me to calm down, because then I am usually worked up.'

'My mom isn't a nurse, but she still gives the best advice.'

'I still miss home a lot . . my parents are getting older ... I miss their company . . because I hardly speak to them anymore.'

'So I e-mail my mom and we mxit and we talk to each other daily.'

"Especially my mom, she was the driving force that made me feel I keep going.

(Study participants)

\section{Lecturers}

The participants reported that they were very close to their lecturers and that they could talk to them and discuss problems with them: 
'They are supportive and let's say, helpful, if you have problems you can go and talk to them about it."

'Nice, because the lecturers know your name and your results, they know you intimately.

(Study participants)

It seems however, that some lecturers became too involved with the participants. A number of the participants said that the lecturers and fellow nursing students gossiped about one another and that nothing remained confidential. Other participants believed that the lecturers did not always respect their personal space and did not always maintain their role as lecturers:

'I know of lecturers who spread stories about us amongst one another.'

'Sometimes it gets too personal in our faculty.'

'Everyone knows everything about everyone and your personal things are never your . . . if you are grumpy today, everyone wants to know why.'

(Study participants)

\section{Theme 3: Collective well-being}

Collective well-being in this context refers to the larger nursing community of which the nursing students formed a part. Collective well-being enables the attainment of personal goals because such goals are achievable only when necessary resources and support are available within the nursing community.

\section{Challenging working environment}

The environment that the participants were exposed to during training could be described as challenging because of a lack of equipment, or equipment that did not function properly. The participants mentioned instances where they could not assist patients because of the inadequate resources available to them. They also felt that some of the patients could have been saved had the appropriate resources been available.

In the following extract, a student describes a situation where she did not receive assistance from any of the nurses on duty because of staff shortages and consequently had no alternative, except to do her best for the particular patient:

'I remember in ward eight, there was a patient that needed oxygen, but there wasn't any at her bed so I had to run down the hall looking for oxygen for the patient. The emergency trolley wasn't ready so I had to run to get the stuff. We had to call the doctor to come and shock her with those things, but there weren't any in the ward. Who knows, maybe she would have survived if there were. By the time I had everything and got back to her room, she was already dead.'

(Study participant)

Other extracts relate a similar story:

'He [the patient] fell out of his bed because he was confused. The nurse was told that he was confused and she was meant to put the sides of his bed up so that he wouldn't fall off. But there weren't any, she should have rather put him on the floor then he wouldn't fall.'

(Study participant)
Another participant added:

'Later she was on the phone with the doctor. She told him: Doctor I am a student and there's no one else here to help me, you'll have to tell me what to do over the phone, we can't just leave the patient like this.'

(Study participant)

\section{Lack of role models in clinical practice}

A role model is someone who knowingly or unknowingly acts as a person whose behaviour is emulated by someone else. Role models hold certain positions in the nursing system, but the participants reported that their role models did not always act in a way that was consistent with their supervisory role (Searle \& Pera 1995:198). Although nurse role models are meant to motivate student nurses in a clinical setting (Chabeli 1999:27), the participants often did not regard the nurses in a positive light (Searle \& Pera 1995:253). Some of the participants cited instances where the nurses who were meant to guide them did not follow the correct procedures but merely tried to complete the work as opposed to carrying it out thoroughly:

'You get staff that are [sic] just not interested in teaching you anything.'

'They refuse to help you from first year to fourth year.'

'In the government hospital there is no support. There is nothing. You feel like if you go to the hospital today, what is going to happen today, will I make it.'

(Study participants)

These participants felt ill equipped to deal with the challenges of the harsh training environment:

'I remember STUDENT X and I looking at each other and we really want to help the man, but we don't know what to do and she [nurse] just kept screaming about things that had no relevance to the situation.'

(Study participant)

Many of the participants said that the nurses had become hard and had somehow lost their compassion and their 'heart' for nursing. Exposure to such attitudes had a negative effect on the participants' vision of becoming nurses:

'Our first cadaver, they just left, they didn't even pack him. He died eight o'clock that morning and no-one packed him until seven o'clock that evening.'

'The staff working there no longer have [sic] the love for it that they had at the beginning. The patients are just another person [sic] to them.'

'At that stage I thought it was okay and everything, but it feels as though I have to become tough on the inside in order to study nursing.'

(Study participants)

\section{Incongruence between theoretical and practical training}

The participants reported that clinical situations did not always match the descriptions in their textbooks. The reallife situations that nurses and nursing students encounter cannot always be resolved or explained through the linear application of theories but rather involve more complex processes that require juggling demands, intuitional experience and knowledge (Kim 1999:1206). The lecturers do not accompany the participants during practical training, and consequently they cannot act as role models and mentors for the participants during practical work. As a result there is 
incongruence between the theoretical training and the actual procedures that participants are told to follow in the practical training:

$$
\begin{aligned}
& \text { 'I also know that our text books say one thing and what happens in } \\
& \text { practice is a totally different thing.' }
\end{aligned}
$$

'It is really like that because on the one hand you have what the books say and on the other hand you have what happens in the hospital."

(Study participants)

The participants also expressed a need for help from the lecturers on how to deal with the gap between their training and the actual nursing practice:

"The lecturers are only in the classroom and teach us there. But in practise there is no one to teach and help us. We actually want them there.'

(Study participants)

\section{Ethical considerations}

This study constitutes part of a project entitled, 'An exploration of enabling contexts', for which ethical permission was granted (\# 05K14) for the present study. The participants were told about the research project, and their informed consent was obtained. The participants were also advised that they could withdraw from the research at any point and that there were an intern psychologist available to them should they desire to talk to someone at any time during their training or during the study. Confidentiality and anonymity of the source material were maintained.

\section{Trustworthiness}

The guidelines suggested by Lincoln and Guba (1985:219) were used to ensure the trustworthiness of the research process. The credibility of the findings was maintained through the focus group discussion held 2 years later. Data gathering during 2008 took place on two separate occasions and the focus group meeting held with the students in 2010 contributed to the integrity of the findings through prolonged engagement. Peer examination and member control were considered by means of group discussions with participants. The findings from this focus group were added to the secondary data that had been gathered from the same participants two years previously (Conrad \& Serlin 2006:414). Transferability of the data was ensured through detailed descriptions of the culture of the participants, of the research context and of the data collection and analysis process (Graneheim \& Lundman 2004:109). The experiences of the participating nursing students were illustrated through verbatim quotes. Dependability of the data was ensured through code-recode procedures of the data (Krefting 1991:15). Confirmability of the data was ensured through the triangulation of theories as well as through the inclusion of a detailed account of the data collection and analysis process (Stommel \& Wills 2004:288). The triangulation of data collection methods contributed to the confirmability of the data. Data were gathered using visual methods as well as individual interviews and focus groups. The size of the interview groups and the informal conversational style in which they were conducted allowed the students to reflect freely on their experiences. The themes generated during the analysis of data collected in 2008 were used as a basis for the subsequent focus group in 2010. The longitudinal approach of another focus group in 2010 provided opportunities to explore the themes that emerged from the various methodologies.

\section{Discussion}

The findings in this research should be seen against the background of the many adverse circumstances that nursing students had to contend with during their first few weeks of training. A number of the students were away from home, often for their first time, and they had to adapt to academic workloads and practical-training hours as well as acquire the coping skills to manage the new challenges.

The students reported high levels of stress and anxiety during their training and described feelings of pressure because of the long hours and heavy workloads. Similar findings are reported by Jones and Johnston (1997:480) as well as by Evans and Kelly (2004:479). The cumulative effect of these new experiences might have affected the adaptive resources of the students and left them overwhelmed and disempowered. The loss of control and the pressure the nursing students experienced, especially during their first year, might have impacted on their self-efficacy and made them particularly vulnerable to stressor events (Dolan 2007:105). Self-efficacy is closely linked to the belief that one is able to achieve a difficult task and also acts as a buffer against the negative impact of stressors (Sivanathan, Arnold, Turner \& Barling 2004:2). The students reported their loss of control and the high demands made on them especially during the initial stages of the training.

Despite the pressures the nursing students mentioned, many of them maintained a positive attitude and retained the desire to become nurses. The choice to view situations positively, and consequently experience more positive emotions over time, can improve a person's psychological resilience and personal well-being (Csikszentmihalyi \& Csikszentmihalyi 2006:95; Huppert, Baylis \& Keverne 2005:230). Students with a positive disposition will be more inclined to transform seemingly negative external events into something meaningful, regardless of the current negative impact (Cooper, Duggleby \& Penz 2009:2381). There is evidence that an optimistic attitude and problem-solving behaviour helps nursing students to deal with stress more effectively (Sheu, Lin \& Hwang 2002:174).

The majority of nursing students in their first year reported that the nursing science course did not fulfil their expectations of nursing as a profession. Similar results are mentioned by Wright (2005:67) and, according to Montmarquette, Mahseredjian and Houle (2001:479), students may drop out if they become disillusioned with their career choice. The students in the study started out with a desire to help people or to work in a medical field, but apart from this, they did not have any real idea of what would be expected of them as nursing students and ultimately as nurses. The students 
expressed disappointment at choosing a study direction they experienced as being different to what they had expected. Although this sentiment usually changed during the students' progression in their studies, it is a factor that requires attention.

Many of the students expressed the hope that they would make a contribution as nurses, which kept them focused on achieving their goal. Hope and optimism are typical amongst individuals who have identified a purpose in their lives (Bronk et al. 2009:506). According to Lopez and Snyder (2002:610), a sense of purpose involves the intention to achieve a goal that has personal significance as well as a positive impact that is external to the self. The nursing students in this study expressed a desire to care for sick patients and to make a contribution. Identifying their own purpose might thus have contributed to their ability to persevere in the achievement of their goals (Corey 2008:100).

Relational well-being includes support from friends, family members and lecturers. The students' reports indicated that the relationships they developed during the course of their training as well as the relationships with their families were important sources of comfort and encouragement. The social support the students experienced contributed to their ability to cope with stress which is supported in literature (Pierce 1997:141; Hobfoll 1986:233; Fink 2000:481). The findings also indicated that the students' social support had a beneficial effect on their psychological well-being (Huppert et al. 2005:509). The communal sense experienced by the nursing students contributed to their feelings of membership, the fulfilment of their needs and shared emotional connection, factors that have been found to contribute to personal coping ability and overall health (Farrell, Aubty \& Coulombe 2004:21). This is consistent with the findings of Manning et al. (2009:170) as well as Roberts (2009:370).

Collective well-being seemed to be challenged the most and the nursing students were outspoken about the unhealthy broader context in which they had to function. In terms of the behaviour-setting theory of Barker (1968:137), nursing students who enter new settings in their first year have to adapt without knowing exactly what is expected of them. According to this theory, a social setting is a well-defined spatial area, a boundary zone, and when it is entered it causes people to change or adapt their behaviour in a more or less conscious way (Barker \& Schoggen 1973:49). The nursing environment, which includes the nurses in the clinics and hospitals as well as the lecturers and fellow students, affects students in different ways.

The staff shortages and the conditions in hospitals lead to a situation where nurses are exhausted, frustrated and stressed. These nurses now have the added pressure of creating a positive image of nursing for the students they have to train. As a consequence of the current state of nursing in South Africa, professional nurses may appear to have a negative attitude that first-year nursing students interpret as lack of consideration toward patients. They may conclude that nurses no longer have a passion for nursing because of their failure to do their work thoroughly in hospitals. Oermann (1998:197) and Thomas and Hume (1998:41) argue that unsupportive staff and the failure to provide students with support are stressors for the students.

The practical component of nurses' training is a vital part of students' training. Their first contact with practical training comes as a surprise, and the environment they have to work in may not be what they expected. What they deal with and experience at the outset of their training is to a large extent a reflection of the nursing profession in general, namely strenuous workloads, high stress levels, poor working conditions, low autonomy and limited free time. Shortages of staff and equipment are also mentioned by Makupu and Botha (2000:14) who state that the lack of equipment and poor working conditions make it difficult for student nurses to achieve meaningful learning.

Students experience confusion when a discrepancy exists between what is taught to them in their academic training and what is actually experienced in the clinical environment (Carlson, Kotze \& Van Rooyen 2003:36). This theory-practice gap is a source of stress for many students, which may contribute to the emotions nursing students often describe as exhaustion and pressure (Lindop 1999:971). The findings of the present study mirror those of a study conducted at the University of Port Elizabeth, namely that factors that contribute to student anxiety are shortages or the absence of equipment needed to fulfil nursing duties as well as the unavailability of support from experienced nurses because of time constraints (Carlson, Kotze \& Van Rooyen 2003:30).

\section{Limitations of the study}

The limited sample size means that the research results cannot be applied to all nursing students in South Africa. A major limitation was that many of the students dropped out of the study, and many did not participate in the focus group meeting during their third year. The second round of data gathering was also representative only of students who progressed to the third year. The experiences of students who dropped out were not taken into account during the second phase, and the research was conducted in a continuously changing environment. Intakes in other years may not have the same experiences as the research sample in the present study. Further studies could also include nursing students from colleges.

\section{Recommendations}

An orientation session should be held before the start of the first-year programme. Senior students should share their experiences, answer questions and advise new students. A clear outline of the academic requirements as well as the practical requirements of the course should be made available to students on the internet. Information about holidays and weekends should be provided, as well as the hours the students will be expected to work in clinics and hospitals, and the demands of the course. 
Prospective nursing students should spend some time in a clinical environment to see first-hand what nursing involves and to expose them to the conditions they will be expected to train and work in, once they are registered nurses.

The course should be re-scheduled to allow students more time to practise crucial skills before applying them in the practical environment. With more time allocated for simulation of clinical tasks, students should be able to accomplish more tasks at an earlier stage during their practical training, and they should be exposed to different aspects of nursing from early on in the course.

Senior and first-year students should be allocated to the same wards for shift work. The presence of more experienced nursing students will make the practical training less stressful for the less experienced students.

Nursing students have to undergo 4000 hours of clinical training during their studies. Granting them more freedom to decide on their own study times may improve their levels of autonomy and self-determination. If students were allowed to work the hours they preferred, they might work extra hours during the semester so that they could go home during the holidays and spend time with their families who are a valuable support system for them.

Most students enter the world of nursing when they are very young and inexperienced, and they are exposed to difficult situations and a high-stress environment. Teaching students stress management techniques as part of the course may help them to cope with the pressures and demands they are exposed to. Weekly group sessions, where students can share experiences outside the classroom environment, may also be beneficial to the students. Such sessions could even be incorporated into the more senior students' timetable so that all nursing students could become acquainted in a relaxed setting and the younger students could receive on-going guidance from the more senior students.

An intern psychologist should be available to students for counselling. Students should not have to consult with their lecturers or arrange counselling via them.

The nurses in charge of supervision during clinical training often make students feel uncomfortable and unwelcome. These nurses are going to be responsible for the practical training of the students and consequently they should be alerted to their influence on the students as well as the nurturing needed by the newcomers. Nurses involved in training should be encouraged to be positive in their interactions with the students, to build the students' selfesteem and to reinforce the value of nurses in hospitals.

\section{Conclusion}

The well-being of nursing students is crucial as they enter the workforce and face the accompanying challenges. Students often find it difficult to adjust to the pressures of the training and the lack of autonomy during their first year. Optimism and a sense of purpose in their nursing studies help them to deal with stress more effectively. Also, the relational well-being of nursing students contributes to their eventual adjustment in the nursing profession. In line with community psychology's approach of studying people in their contexts, this research highlighted serious concerns about a collective environment that is not conducive to the holistic well-being of nursing students as well as patients.

\section{Acknowledgements}

The authors would like to acknowledge the contribution of the participants as well as Ms M. van Deventer, the intern research psychologist, who assisted with data collection.

\section{Competing interests}

The authors declare that they have no financial or personal relationship(s) which may have inappropriately influenced them in writing this article.

\section{Authors' contributions}

K.W. and V.R. designed the study, analysed and interpreted the data and wrote the first draft of the discussion. E.v.d.W. was involved as an expert of nursing sciences and critique.

\section{References}

Alacacioglu, A., Yavuzsen, T., Dirioz, M., Oztop, I. \& Yilmaz, U., 2009, 'Burnout in nurses and physicians working at an oncology department', Psycho-Oncology 18(5), 543548. doi:10.1002/pon.1432, PMid:18942658

Babbie, E., 2007, The practice of social research, 11th edn., Thomson/Wadsworth, Belmont, MA.

Barker, R.G., 1968, Ecological psychology: Concepts and methods for studying the environment of human behaviour, Stanford University Press, Stanford, CA.

Barker, R.G. \& Schoggen, P., 1973, Qualities of community life: Methods of measuring environment and behavior applied to an American and an English town, JosseyBass, San Francisco, CA.

Brannigan, E., 2009, 'Task shifting', Nursing Update 37, 36-37.

Braun, V. \& Clarke, V., 2006, 'Using thematic analysis in psychology', Qualitative Research in Psychology 3(2), 77-101. doi:10.1191/1478088706qp063oa

Bronk, K.C., Hill, P., Lapsley, D., Talib, N. \& Holmes, W.F., 2009, 'Purpose, hope, and life satisfaction among adolescents', Journal of Positive Psychology 6(4), 500-510.

Brysiewicz, P. \& Bruce, J., 2008, 'Emergency nursing in South Africa', International Emergency Nursing 16(2), 127-131. doi:10.1016/j.ienj.2008.01.001, PMid:18519064

Bukowski, W.M., Newcomb, A.F. \& Hartup, W.V., 1996, 'Friendship and its significance in childhood and adolescence: Introduction and comment', in W.M. Bukowski, A.F. Newcomb \& W.V. Hartup (eds.), The Company They Keep: Friendship in childhood and adolescence, n.p., Cambridge University, New York.

Carlson, S., Kotze, W.J. \& Van Rooyen, D., 2003, 'Accompaniments needs of first year nursing students in the clinical learning environment', Curationis 26(2), 30-39. PMid:14596131

Chabeli, M., 1999, 'Students nurses' learning needs and expectations in the clinical learning units', Curatonis 22(4), 24-28.

Conrad, C. \& Serlin, R.C., 2006, The Sage handbook for research in education: engaging ideas and enriching inquiry, SAGE Publications, Inc., Thousand Oaks, CA.

Cooper, D., Duggleby, W. \& Penz, K., 2009, 'Hope, self-efficacy, spiritual well-being and job satisfaction', Journal of advanced nursing 65(11), 2376-2385. doi:10.1111/ j.1365-2648.2009.05094.x, PMid:19737323

Corey, G., 2008, Theory and practice of psychotherapy and counselling, Brooks Cole, Pacific Grove, CA.

Csikszentmihalyi, M. \& Csikszentmihalyi, I.S., 2006, A life worth living: Contributions to positive psychology, Oxford University Press, New York.

Dalton, J.H., Elias, M.J. \& Wandersman, A., 2003, Community Psychology: Linking Individuals and Communities, Wadsworth, Stamford, CT.

Dolan, S.L., 2007, Stress, self-esteem, health and work, Palgrave Macmillan, New York. 
Evans, M.D.R. \& Kelly, J, 2004, Australian Economy and Society 2002: Religion, Morality and Public Policy in International Perspective 1984-2002, The Federation Morality and Pubs, Sydney.
Press

Farrell, S.J., Aubty, T. \& Coulombe, D., 2004, 'Neighborhoods and neighbors: Do they contribute to personal well-being?', Journal of community psychology 32(1), 9-25. doi:10.1002/jcop.10082

Fink, G., 2000, Encyclopedia of Stress, Academic Press, London.

Gillham, J.E., 2000, The Science of Optimism and Hope: Research Essays in Honor of Martin E.P. Seligman, Templeton Foundation Press, Philadelphia, PA.

Graneheim, U.H. \& Lundman, B., 2004, 'Qualitative content analysis in nursing research: concepts, procedures and measures to achieve trustworthiness', Nurse Education Today 24(2), 105-112. doi:10.1016/j.nedt.2003.10.001, PMid:14769454

Green, J. \& Thorogood, N., 2004, Qualitative methods for health research, SAGE Publications, Inc., Thousand Oaks, CA.

Hobfoll, S.E., 1986, Stress social support and women, Hemisphere, Washington DC.

Huppert, J.D., Moser, J.S., Gershuny, B.S., Riggs, D.S., Spokas, M., Filip, J. et al., 2005, 'The relationship between obsessive-compulsive and posttraumatic stress symptoms in clinical and non-clinical samples', Journal of Anxiety Disorders 19(1) 127-136. doi:10.1016/j.janxdis.2004.01.001, PMid:15488372

Huppert, F.A., Baylis, N. \& Keverne, B., 2005, Science of well-being, Oxford, New York. Jacobs, E. \& Roodt, G., 2008, 'Organisational culture of hospitals to predict turnover intentions of professional nurses', Health SA Gesondheid 13(1), 63-78.

Jones, M.C. \& Johnston, D.W., 1997, 'Distress, stress and coping in first year student nurses', Journal of Advanced Nursing 26(45), 475-482. doi:10.1046/j.1365-2648.1997.t01-5-00999.x, PMid:9378866

Kim, H.S., 1999, 'Critical reflective inquiry for knowledge development in nursing practice', Journal of advanced nursing PMid:10320505

Keenan, J., 1999, 'A concept analysis of autonomy', Journal of advanced nursing 29(3), 556-562. doi:10.1046/j.1365-2648.1999.00948.x, PMid:10210450

Krefting, L., 1991, 'Rigor in qualitative research: The assessment of trustworthiness', The American journal of occupational therapy 45(3), 214-222.

Lincoln, Y.S. \& Guba, E.G., 1985, Naturalistic Inquiry, SAGE Publications, Newbury Park, CA.

Lindop, E., 1999, 'A comparative study of stress between pre- and $\begin{array}{lccccc}\text { post-Project } 2000 \text { Students', Journal of Advanced Nursing } \\ 29(4) . & 967-973 . & \text { doi:10.1046/j.1365-2648.1999.00974.x, }\end{array}$ 29(4),
PMid:10215990 967-973.

Lopez, S.J. \& Snyder, C.R., 2002, Handbook of Positive Psychology, Oxford University Press, New York.

Makupa, M.B. \& Botes, A., 2000, 'The community health clinics as a learning contex for student nurses', Curationis 23(3), 12-19. PMid:11949151

Manning, A., Cronin, P., Monaghan, A. \& Rawlings-Anderson, K., 2009, 'Supporting students in practise: An exploration of reflective groups as a means of support', Nurse Education in Practise 9(3), 176-183. doi:10.1016/j.nepr.2008.07.001, PMid:18786861
Marsh, H.W., 1992, 'Content specificity of relations between academic achievement and academic self-concept', Journal of Educational Psychology 84(1), 35-42. doi:10.1037/0022-0663.84.1.35

Mascaro, N., Rosen, D.H. \& Morey, L.C., 2004, 'The development, construct validity, and clinical utility of the spiritual meaning scale', Personality and Individual Differences 37(4), 845-860. doi:10.1016/j.paid.2003.12.011

McDonald, D.A. \& Crush, J., 2000, 'Understanding skilled migration in South Africa', Africa Insight 30(2), 10-20.

McGrath, S.A., 2003, 'Sectoral insights into the scarce skills debate', HSRC Review 1(2), 10.

Minnaar, A. \& Selebi, C., 2009, 'Our greatest loss', Nursing Update 33(6), 29-35.

Montmarquette, C., Mahseredjian, S. \& Houle, S., 2001, 'The determinants of university student dropouts: a bivariate model with sample selection', Economics of Education Review 20(5), 475-484. doi:10.1016/S0272-7757(00)00029-7

Nelson, G. \& Prilleltensky, I., 2005, Community psychology: In pursuit of liberation and well-being, Palgrave MacMillan, China.

Oermann, M.H., 1998, 'Differences in clinical experiences of AND and BSN students', Journal of Nursing education 37(5), 197-201. PMid:9605192

Oosthuizen, M. \& Ehlers, V.J., 2007, 'Factors that may influence South African nurses' decisions to emigrate', Health SA Gesondheid 12(2), 14-26.

Pierce, G.R., 1997, The Sourcebook of Social Support and Personality, Plenum Press, Lippincott Williams \& Wilkins, New York.

Prilleltensky, I. \& Prilleltensky, O., 2006, Promoting well-being. Linking personal, organizational and community change, John Wiley \& Sons, New Jersey.

Recker, G.T. \& Wong, P.T.P., 1988, 'Aging as an individual process: Toward a theory of personal meaning', in J.E. Birrer \& V.L. Bengtson (eds.), Emergent theories of aging, pp. 214-246, Springer Publishing Company, New York.

Roberts, D., 2009, 'Friendship fosters learning: The importance of friendships in clinical practice', Nurse education in practice 9(6), 367-371. doi:10.1016/j. nepr.2008.10.016, PMid:19084479

Roos, V., (in press), 'The Mmogo-method ${ }^{\mathrm{TM}}$ : An Exploration of experiences through visual Projections', Qualitative Research in Psychology.

Roos, V., 2008, 'The Mmogo-method ${ }^{\mathrm{TM}}$ discovering symbolic community interactions', Journal of Psychology in Africa 18(4), 659-668.

Searle, C. \& Pera, S.A., 1995, Professional practice: A South African perspective, Butterworths, Durban.

Sheu, S., Lin, H.S. \& Hwang, S.L., 2002, 'Perceived stress and physio-psycho-social status of nursing students during their initial period of clinical practice: the effect of coping behaviors', International Journal of Nursing Studies 39(2), 165-175. doi:10.1016/S0020-7489(01)00016-5

Sivanathan, N., Arnold, K.A., Turner, N. \&Barling, J., 2004'leading well: Transformational leadership and well-being', in P.A. Linky \& S. Joseph (eds.) Positive Psychology in practice, pp.241-255, John Wiley \& Sons, Inc, New Jersey.

Stommel, M. \& Wills, C.E., 2004, Clinical research: Concepts and principles for advanced practise nurses, Lippincott Williams \& Wilkins, Philadelphia, PA.

Thomas, S. \& Hume, G., 1998, 'Delegation competencies: Beginning practitioner's reflections', Nurse Educator 23(1), 38-41. PMid:9505694

Wright, S.C.D., 2005, 'Student satisfaction', unpublished research, Tshwane University of Technology, Pretoria. 